\title{
SURFACE WATER DATA NETWORK \\ ANALYSIS FOR PUERTO RICO
}

By Patrick W. McKinley

U.S. GEOLOGICAL SURVEY

WATER-RESOURCES INVESTIGATIONS

REPORT 83-4055

Prepared in cooperation with the

PUERTO RICO DEPARTMENT OF NATURAL RESOURCES

San Juan, Puerto Rico

1985 


\section{UNITED STATES DEPARTMENT OF THE INTERIOR \\ WILLIAM P. CLARK, Secretary}

\section{GEOLOGICAL SURVEY}

Dallas L. Peck, Director

For additional information write to:

Chief, Caribbean District, WRD U.S. Geological Survey GPO Box 4424 San Juan, PR 00936

(Telephone: (809) 753-4414)
Copies of this report can be purchased from:

Open-file Services Section Western Distribution Branch U.S. Geological Survey Box 25425. Federal Center Denver, Colorado 80225 (Telephone: (303) 234-5888) 
Abstract....................................... 1

Introduction. $\ldots \ldots \ldots \ldots \ldots \ldots \ldots \ldots \ldots \ldots \ldots \ldots \ldots \ldots \ldots \ldots \ldots$

Description of regression equations.................... 2

Method of evaluation............................. 7

Gaging network design................................. 9

Conclusions....................................... 11

References.......................................... 14

\section{ILLUSTRATIONS}

Figure 1. Map showing geographic location of gaging stations used

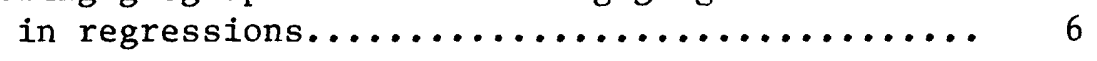

2. Diagram showing true standard error for the (A), mean annua 1 discharge, (B), 2-year, (C), 10-year, (D), 50-year, and, (E), 100-year flood.........

3. Diagrams showing NB-NY frontier overlaid on lines of standard error of estimate for the 2-year peak flood analysis for 5-, 10-, and 20-year planning horizon.............................. 10

\section{TABLES}

Table 1. Description of regression equations............... 3

2. Stations used in developing the regression equations, years of record analysed, and selected basin

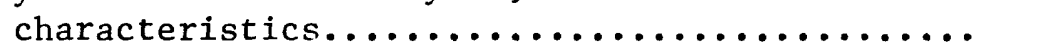

3. Stations included in the 5-, 10-, and 20-year planning horizons.......................... 9

4. Recommended network and cooperators.............. 12 


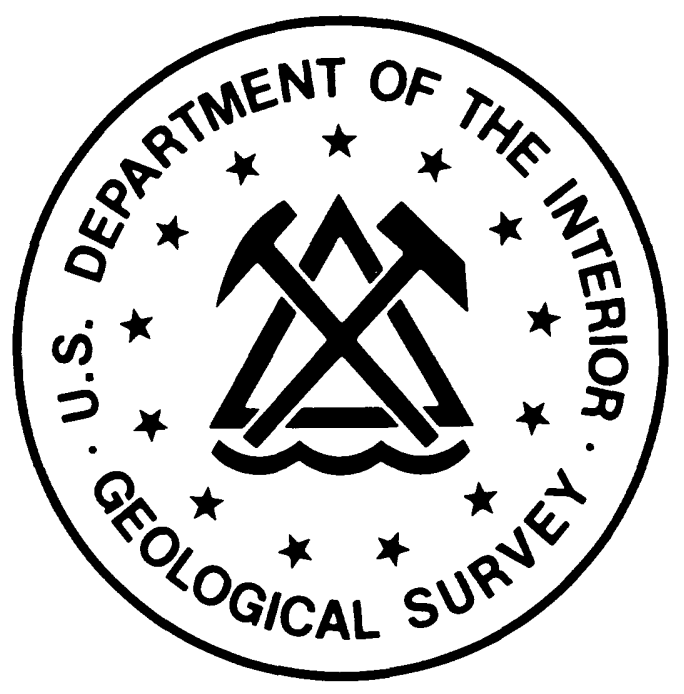

ACKNOWLEDGMENTS

Drafting and Art...._. Jose Alicea

Typlng/Editing.............Carmen A. García 


\title{
SURFACE WATER DATA NETWORK ANALYSIS FOR PUERTO RICO
}

\author{
by \\ Patrick W. McKinley
}

\begin{abstract}
The streamflow data collection network of Puerto Rico has been evaluated by a computer modeling technique known as NARI (Network Analysis for Regional Information). This technique utilizes the hydrologic information available from the present network to provide a basis for developing a future gaging network. The mean annual discharge, 2-year, 10-year, 50-year, and 100-year peak discharges were used as dependent or response variables in the regression analysis of the network. Other hydrologic characteristics such as low-flow were not analyzed.

Regression equations were calculated for the whole island

of Puerto Rico using mean annual precipitation for the basin, and drainage area as independent or predictor variables. The standard error of estimate of regression varied from 21 percent for the mean annual discharge to 44 percent for the 100-year flood.

The results of the statistical analyses show a shortage of long-term records. The harmonic mean-record length for the flood analysis was only 8 years. A long-term network of 16 stations is proposed which if continued would decrease the statistical error in transfering data to ungaged sites, identification of trends, and future modeling efforts.
\end{abstract}

\section{INTRODUCTION}

Streamflow data-collection programs normally develop from the hydrologic-information needs of the data users. Special data-collection projects, which have a limited life and sçope, often answer these needs. Hydrologists and planners also have recognized the need to anticipate data demands as insurance against decisions based on too little or inadequate hydrologic data (Moss, Lettenmaier, and Wood, 1978). In order to meet future data demands, the Commonwealth of Puerto Rico in cooperation with the U.S. Geological Survey developed and maintains a network of streamflow stations to serve as a base of hydrologic information that can be transferred to ungaged sites. This network must be periodically reevaluated and modified to reflect the influence of new data and a changing level of understanding of the hydrologic processes on the network design. 


\section{INTRODUCTION - Continued}

In 1981, the U.S. Geological Survey, Water Resources Division, began a statistical evaluation of the current stream-gaging network in Puerto Rico. The project, in cooperation with the Puerto Rico Department of Natural Resources, presents a cost-effective gaging plan to provide basic hydrologic information for the mean-annual discharge, and peak discharges for the 2-, 10-, 50-, and 100-year frequency floods at ungaged sites. Low-flow characteristics were not investigated because of the uncertainty of statistical analyses by regression in low flow studies.
Regional regression equations were developed for Puerto Rico to predict each of these desired statistics at ungaged sites. Utilizing a statistical procedure known as Network Analysis for Regional Information, NARI, (Moss and others, 1982), a relation was developed between the standard error of regression, and the number of stations and record length. The network cost, represented as the number of stations operated, is then related to the standard error.

\section{DESCRIPTION OF REGRESSION EQUATIONS}

\begin{abstract}
Drainage area and mean annual precipitation were used as independent or predictor variables in calculating the regression equations. Drainage area was determined from U.S. Geological Survey 1:20,000 topographic maps. Average annual precipitation was calculated from U.S. Weather Service data using the isohyetal method. For each equation an associated standard error of regression was computed (an estimate of how well the observed data fit the regression mode1). Residuals from the regression equations were plotted by latitude and 1ongitude to identify areas of hydrologic similarity. The
\end{abstract}

island was then divided into areas of similar hydrologic and geographic characteristics in an attempt to minimize the standard error. This method failed to decrease the standard error and therefore equations modeling the whole island were used instead of smaller regional equations.

A Statistical Analyses System (SAS) (Barr and others, 1976) was used to compute the regression equations and associated standard error. Discharge data were obtained from the U.S. Geological Survey WATSTORE files. The equations developed are shown in table 1. 


\section{DESCRIPTION OF REGRESSION EQUATIONS - Continued}

Table 1.--Description of regression equations.

\begin{tabular}{|c|c|c|}
\hline EQUATIONS & $\begin{array}{l}\text { STANDARD } \\
\text { ERROR, } \\
\text { PERCENT }\end{array}$ & $\begin{array}{c}\text { STANDARD ERROR } \\
\text { NATURAL } \\
\text { LOGARITHMIC UNITS }\end{array}$ \\
\hline$=0.0006 \mathrm{~A}^{0.99} \mathrm{P}^{1.86}$ & 21 & 0.211 \\
\hline $\mathrm{Q}_{2}=1.35 \mathrm{~A}^{0.77} \mathrm{P}^{1.38}$ & 36 & .353 \\
\hline$Q_{10}=10.18 \mathrm{~A}^{0.85} \mathrm{P}^{1.06}$ & 35 & .343 \\
\hline$Q_{50}=38.86 \mathrm{~A}^{0.90} \mathrm{P}^{0.85}$ & 41 & .393 \\
\hline$Q_{100}=62.80 \mathrm{~A}^{0.92} \mathrm{P}^{0.77}$ & 44 & .420 \\
\hline
\end{tabular}

Where $Q$ is the stream discharge in cubic feet per second, $A$ is the drainage area in square miles and $P$ is the average mean annual precipitation in inches per year. The subscripts of $Q$ are $m$ for the mean annual discharge and the 2-, 10-, 50-, and 100-year frequency flood peak.

A network of 31 stations used in the mean annual discharge regressions and 24 stations for the peak flow discharges are listed in table 2.
Statistical restrictions caused rejection of stations that had a short record-length or limited peak-flow record. The station locations (figure 1) represent the principal streams in Puerto Rico and/or sites established for specific areal studies. The report by López, Colón, and Cobb (1979) contains flood-frequency equations similar to the above regression equations, however, the equations in that report are not superceded by the equations in this report. 
Table 2.--Stations used in developing the regression equations, years of record analysed, and selected basin characteristics.

\begin{tabular}{|c|c|c|c|c|}
\hline $\begin{array}{l}\text { MAP } \\
\text { REFERENCE } \\
\text { NUMBER }\end{array}$ & STATION NAME & $\begin{array}{c}\text { CONTRIBUTING } \\
\text { DRAINAGE } \\
\text { AREA, } \\
\text { IN SQ MI } \\
\end{array}$ & $\begin{array}{c}\text { ANNUAL } \\
\text { PRECIPITATION, } \\
\text { IN INCHES }\end{array}$ & $\begin{array}{l}\text { YEARS OF } \\
\text { RECORD } \\
\text { ANALYZED }\end{array}$ \\
\hline 1 & *50028000 Río Tanama nr Utuado. & 18.4 & 79.7 & 18 \\
\hline 2 & $\begin{array}{l}50029000 \text { Río Grande de Arecibo at } \\
\text { Central Cambalache. }\end{array}$ & 267.0 & 77.7 & 9 \\
\hline 3 & $\begin{array}{l}\text { *50031200 Río Grande de Manatí nr } \\
\text { Morovis. }\end{array}$ & 55.2 & 79.7 & 12 \\
\hline 4 & *50034000 Río Bauta nr Orocovis. & 16.7 & 81.1 & 8 \\
\hline 5 & $\begin{array}{l}\text { *50035000 Río Grande de Manatí at } \\
\text { Ciales. }\end{array}$ & 128.0 & 75.9 & 16 \\
\hline 6 & $\begin{array}{l}50038100 \text { Río Grande de Manatí at } \\
\text { Hwy } 2 \text { nr Manatí. }\end{array}$ & 159.0 & 73.7 & 8 \\
\hline 7 & *50038320 Río Cibuco at Corozal. & 15.1 & 84.9 & 9 \\
\hline 8 & 50039500 Río Cibuco at Vega Baja. & 66.0 & 70.9 & 5 \\
\hline 9 & $\begin{array}{l}\text { *0043000 Río de la Plata at } \\
\text { Proyecto la Plata. }\end{array}$ & 54.8 & 74.8 & 18 \\
\hline 10 & $\begin{array}{l}{ }^{*} 50046000 \text { Río de la Plata at Toa } \\
\text { Alta. }\end{array}$ & 200.0 & 70.1 & 17 \\
\hline 11 & 50049000 Río Piedras at Río Piedras. & 12.5 & 75.7 & 7 \\
\hline 12 & $\begin{array}{l}\text { *50055000 Río Grande de Loíza at } \\
\text { Caguas. }\end{array}$ & 89.8 & 81.6 & 18 \\
\hline 13 & 50056400 Río Valenciano nr Juncos. & 16.4 & 84.9 & 7 \\
\hline 14 & *50057000 Río Gurabo at Gurabo. & 60.2 & 80.0 & 18 \\
\hline 15 & *50061800 Río Canóvanas nr Campo Rico. & 9.84 & 125.0 & 11 \\
\hline
\end{tabular}


5

Table 2.--Continued

\begin{tabular}{|c|c|c|c|c|}
\hline $\begin{array}{l}\text { MAP } \\
\text { REFERENCE } \\
\text { NUMBER }\end{array}$ & STATION NAME & $\begin{array}{l}\text { CONTRIBUTING } \\
\text { DRAINAGE AREA } \\
\text { IN SQ MI }\end{array}$ & $\begin{array}{l}\text { ANNUAL } \\
\text { PRECIPITATION, } \\
\text { IN INCHES }\end{array}$ & $\begin{array}{l}\text { YEARS OF } \\
\text { RECORD } \\
\text { ANALYZED }\end{array}$ \\
\hline 16 & $\begin{array}{l}\text { *50063800 Río Espiritu Santo nr } \\
\text { Río Grande. }\end{array}$ & 8.62 & 148.0 & 11 \\
\hline 17 & *50064200 Río Grande nr E1 Verde. & 7.31 & 159.0 & 9 \\
\hline 18 & $\begin{array}{l}\text { *50065700 Río Mameyes at Hwy } 191 \\
\text { at Mameyes. }\end{array}$ & 11.8 & 140.0 & 12 \\
\hline 19 & *50071000 Río Fajardo nr Fajardo. & 14.9 & 106.0 & 17 \\
\hline 20 & *50075000 Río Icacos nr Naguabo. & 1.26 & 194.0 & 3 \\
\hline 21 & $\begin{array}{l}\text { *50082800 Río Guayanes nr Colonia } \\
\text { Laura. }\end{array}$ & 4.69 & 120.0 & 9 \\
\hline 22 & 50090500 Río Maunabo at Lizas. & 5.38 & 113.0 & 7 \\
\hline 23 & $\begin{array}{l}\text { *50092000 Río Grande de Patillas } \\
\text { nr Patillas. }\end{array}$ & 18.3 & 86.5 & 12 \\
\hline 24 & *50112500 Río Inabon at Real Abajo. & 9.7 & 81.1 & 12 \\
\hline 25 & *50114000 Río Cerrillos nr Ponce. & 17.8 & 87.0 & 14 \\
\hline 26 & *50115000 Río Portugues nr Ponce. & 8.82 & 86.6 & 14 \\
\hline 27 & *50136000 Río Rosario nr Rosario. & 17.6 & 76.1 & 8 \\
\hline 28 & $\begin{array}{l}50138000 \text { Río Guanajibo nr } \\
\text { Hormigueros. }\end{array}$ & 120.0 & 72.9 & 5 \\
\hline 29 & *50141000 Río Yahuecas nr Adjuntas. & 15.4 & 79.0 & 11 \\
\hline 30 & $\begin{array}{l}\text { * } 50144000 \text { Río Grande de Añasco nr } \\
\text { San Sebastián. }\end{array}$ & 130.0 & 89.9 & 15 \\
\hline 31 & $\begin{array}{l}\text { * } 50147800 \text { Río Culebrinas at Hwy } 404 \\
\text { nr Moca. }\end{array}$ & 71.2 & 93.4 & 11 \\
\hline
\end{tabular}

* Used in peak-flow regression. 


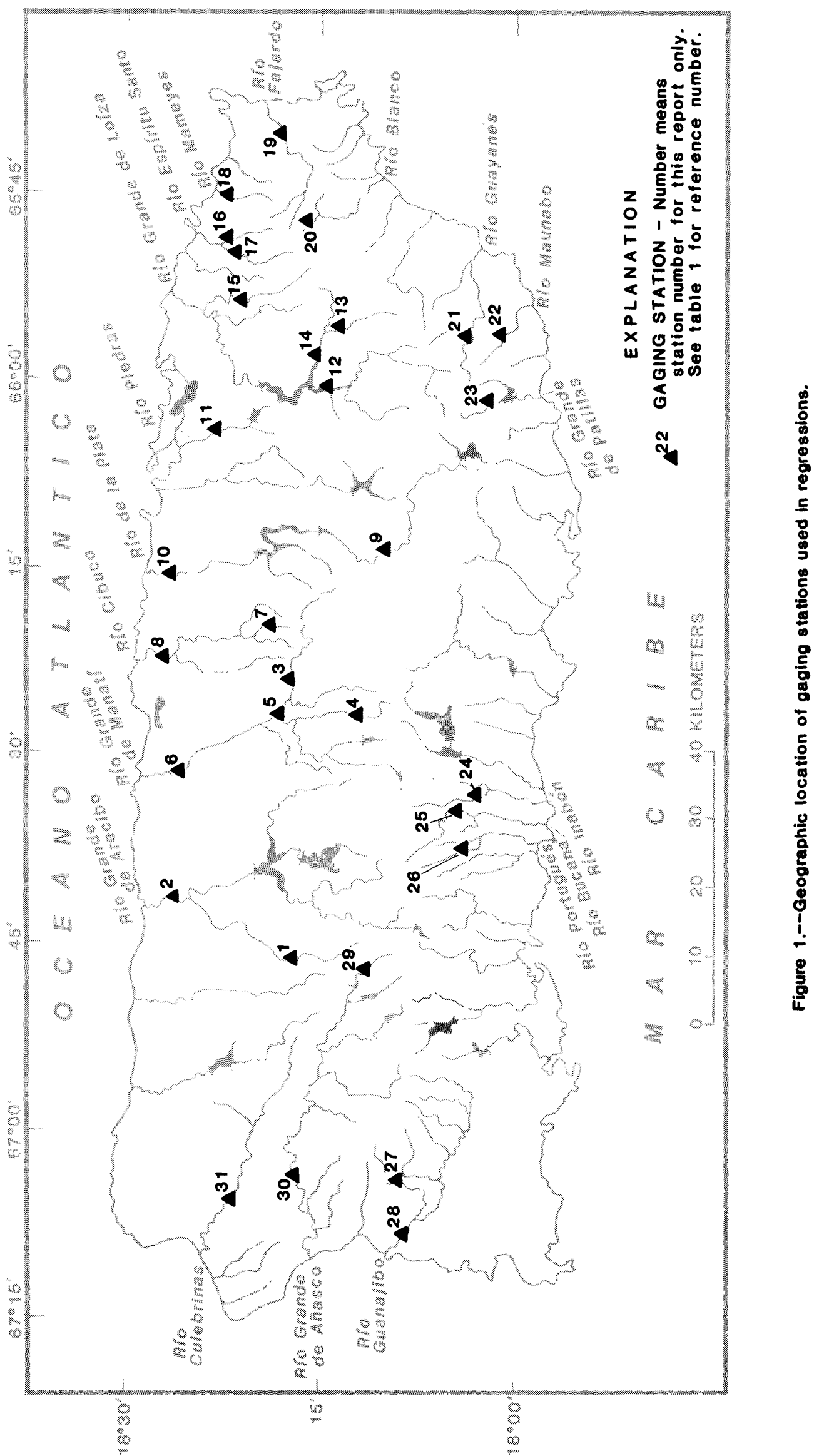




\section{METHOD OF EVALUATION}

The method of evaluation used was a series of computer programs collectively known as NARI, Network Analysis for Regional Information, which is based on the technique of network design introduced by Moss and Karlinger, (1974).

The NARI technique takes the true standard error of estimate of a regional regression (Moss and others, 1982) as a measure of the regional information contained in a data network. Uncertainty in the true standard error of estimate, $S_{t}$, is handled by treating $S_{t}$ as a random variable with $t$ probability density function. Within a hydrologic region, this function is assumed to be dependent only on the following parameters:

(1) NB, the adjusted
number of stations in the
regional regression. NB is
defined by:

$$
\mathrm{NB}=\mathrm{n}-\mathrm{k}+1 \text {, }
$$

Where $k$ is the number of independent variables used in the regression (in this application $k=2$ ) and $n$ is the number of stations used in the regression.
(2) NY, the harmonic mean record length of the stations in the regression. $\mathrm{NY}$ is defined by:

$$
N Y=\left(\sum_{i=1}^{n}\left(m_{i} n\right)^{-1}\right)^{-1}
$$

Where $\mathrm{m}$ is the record length, in years, at the ith station.

(3) $S_{0}$, the observed standard error of estimate. S is an estimate of the standard deviation of the regional regression residuals.

Output from a NARI analysis includes a family of probability distributions of the true standard error indexed by, or conditioned on, values of NB and NY. The 50-percentile point or median true standard error for each distribution is selected and the results plotted as a function of $\mathrm{NB}$ and NY in figure 2 for each flow characteristic.

These graphs represent changes in hydrologic information provided by the network. The standard error decreases as the number of stations and (or) their record lengths increase. The network design, and cost, are affected by the information needs. The available budget may limit the design and acceptable information error. 

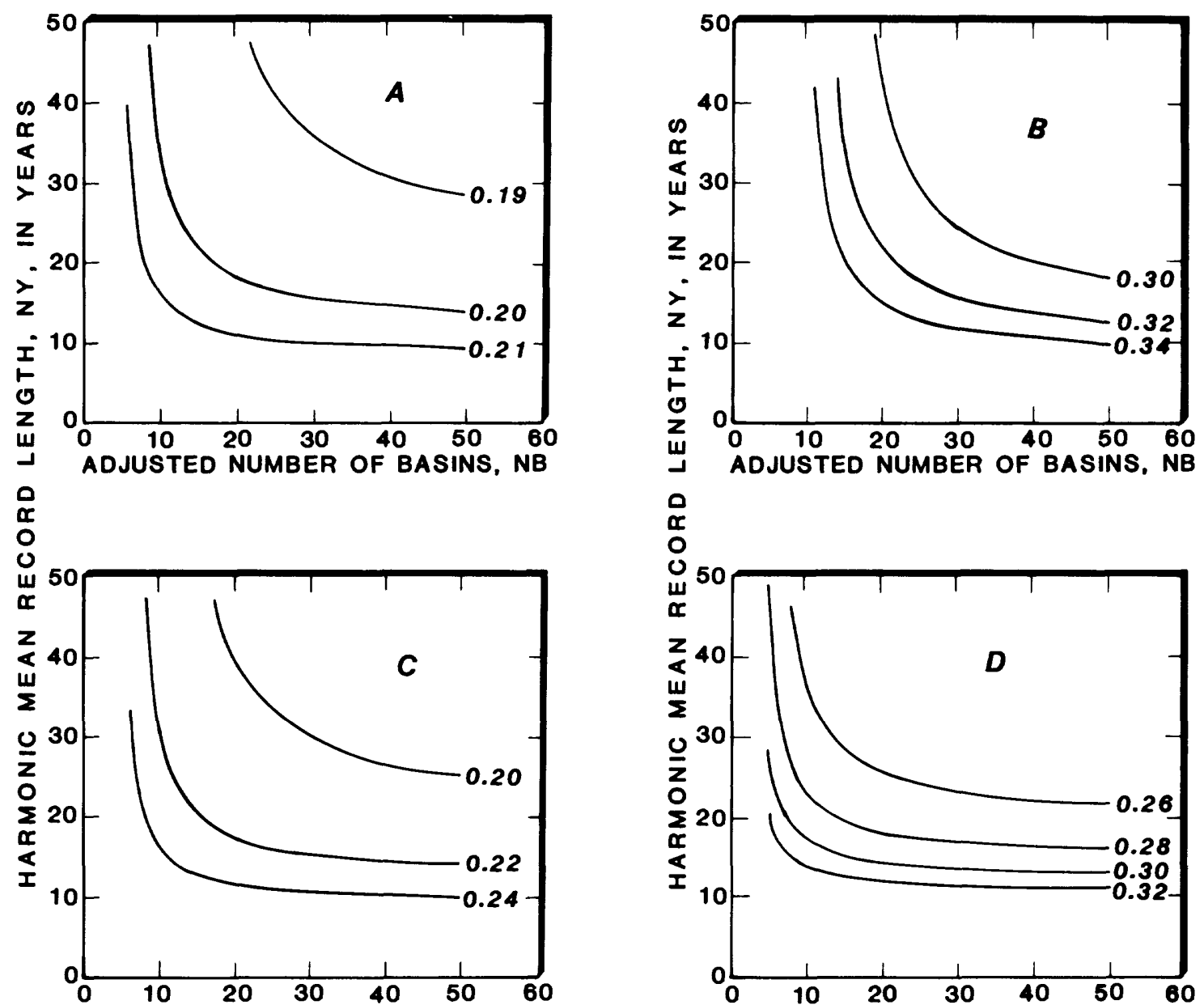

ADJUSTED NUMBER OF BASINS, NB
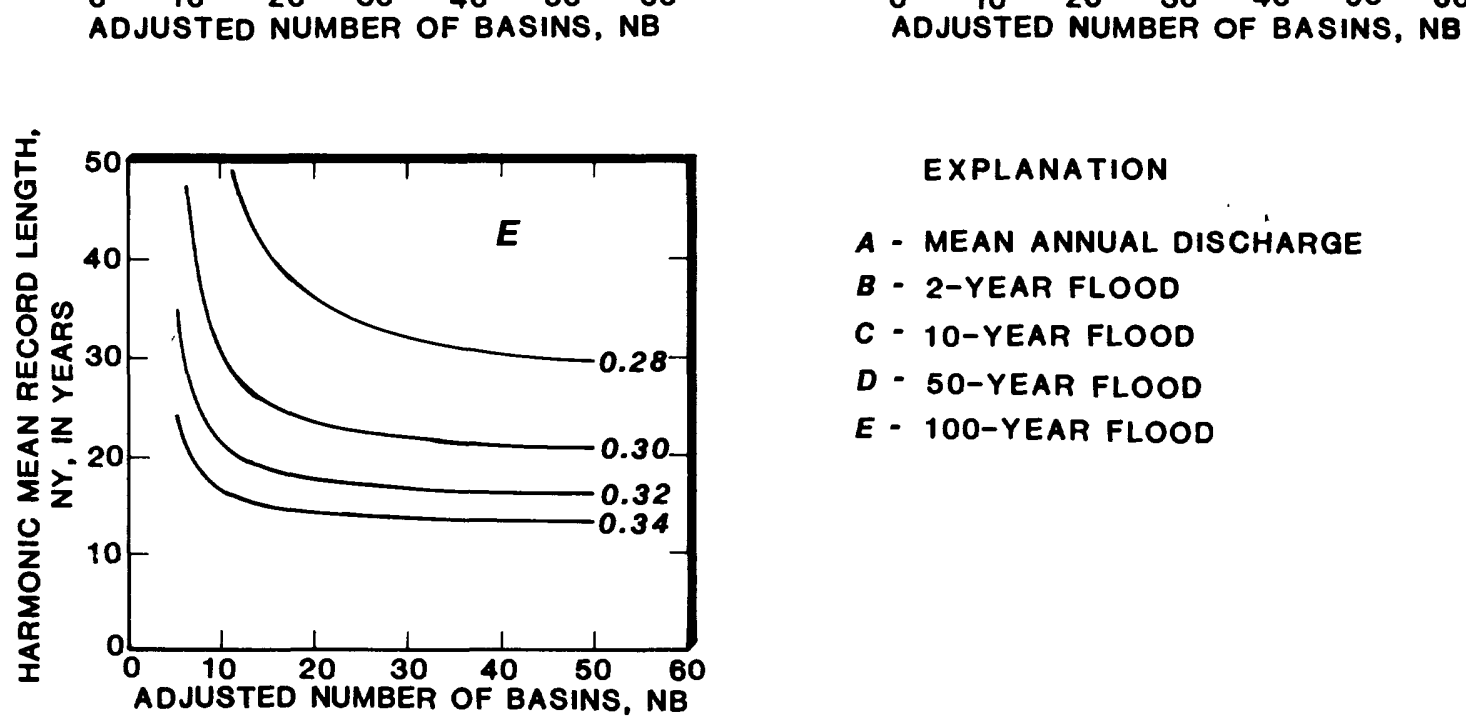

\section{EXPLANATION}

A - MEAN ANNUAL Discharge

$B$ - 2-YEAR FLOOD

C - 10-YEAR FLOOD

D - 50-YEAR FLOOD

E - 100-YEAR FLOOD

Figure 2.--True standard error for the mean annual discharge, 2-year, 10-year, 50-year, and 100-year flood. 


\section{GAGING-NETWORK DESIGN}

The goal of network design is to identify a future gaging plan that is efficient in collecting regional information and also meets the data requirements of special projects.

The NARI technique allows the network designer to preselect the number of gaging sites that must be operated because of project requirements or separate cooperator funding. Stations that are expected to be operated in Puerto Rico during the next 20 years are listed in table 3 . Three gaging networks described as planning horizons (5-, 10-, or 20- years) are distinguished in the 1 ist of stations. The 5-year horizon differs from the 10and 20-year horizon in that it contains short-term stations which are usually associated with specific projects. The 10 and 20-year plans are representative of long-term stations.

Table 3.--Stations included in the 5-, 10-, and 20-year planning horizons.

\begin{tabular}{l|l|r}
\hline $\begin{array}{c}\text { STATION } \\
\text { NUMBER }\end{array}$ & \multicolumn{1}{c|}{ STATION NAME } & $\begin{array}{r}\text { PLANNING } \\
\text { HORIZON }\end{array}$ \\
\hline 50028000 & Río Tanamá nr Utuado & $5,10,20$ \\
50029000 & Río Grande de Arecibo at Cambalache & $5,10,20$ \\
50030460 & Río Orocovis nr Orocovis & 5 \\
50035000 & Río Grande de Manatí Hwy 2 nr Manatí & $5,10,20$ \\
50039500 & Río Cibuco at Vega Baja & $5,10,20$ \\
50046000 & Río de la Plata at Toa Alta & $5,10,20$ \\
50055000 & Río Grande de Loíza at Caguas & $5,10,20$ \\
50056400 & Río Valenciano nr Juncos & $5,10,20$ \\
50057000 & Río Gurabo at Gurabo & $5,10,20$ \\
50067000 & Río Sabana nr Sabana & 5 \\
50071000 & Río Fajardo nr Fajardo & $5,10,20$ \\
50075000 & Río Icacos nr Naguabo & 5 \\
50075500 & Río Blanco at Florida & $5,10,20$ \\
50081000 & Río Humacao at Las Piedras & 5 \\
50092000 & Río Grande de Patillas nr Patillas & $5,10,20$ \\
50112500 & Río Inabón at Real Abajo & $5,10,20$ \\
50114000 & Río Cerrillos nr Ponce & 5 \\
50115000 & Río Portugués nr Ponce & 5 \\
50124200 & Río Guayanilla nr Guayanilla & $5,10,20$ \\
50126150 & Río Yauco above Diversion Monserrate nr Yauco & 5 \\
50128000 & Río Yauco nr Yauco & $5,10,20$ \\
50138000 & Río Guanajibo nr Hormigueros & $5,10,20$ \\
50141000 & Río Yahuecas nr Adjuntas & $5,10,20$ \\
50144000 & Río Grande de Añasco nr San Sebastián & $5,10,20$ \\
50147800 & Río Culebrinas a Hwy 404 nr Moca & \\
\hline
\end{tabular}




\begin{abstract}
NARIPLOT, a computer procedure of NARI, (G.D. Tasker, written commun., 1980), was used to calculate the minimum standard error for each planning horizon as a function of the number of stations operated (fig. 3). The small square on each dashed line denotes the minimum standard error, optimum number of stations in the regression equation, and optimum harmonic mean-record length for the indicated number of stations operated.
\end{abstract}

Minimum regional information is gained by operating more than 25 stations. This is indicated by the small decrease in standard error of estimate as the number of stations increases from 25 to 45 . Selecting the twenty year planning horizon, the most economical plan graphed is for 25 stations. The maximum information that can be attained from this network when NY equals 29 years and NB equals 31 stations is shown in figure 3c. In this scenario, 25 stations are operated during any one year but a total of 31 stations are used in the regression. The standard error for this example is 0.299 (natural logarithmic units).

The advantage of maintaining stations over a long period of time is illustrated in figures 2 and 3 . The present gaging network in Puerto Rico is represented by the small triangle near the bottom of the graph, (figure 3 ). The adjusted number of basins is 23. This is less than the actual number of gaging stations presently operating on the island, but represents those stations that have sufficient years of record to be analysed statistically.
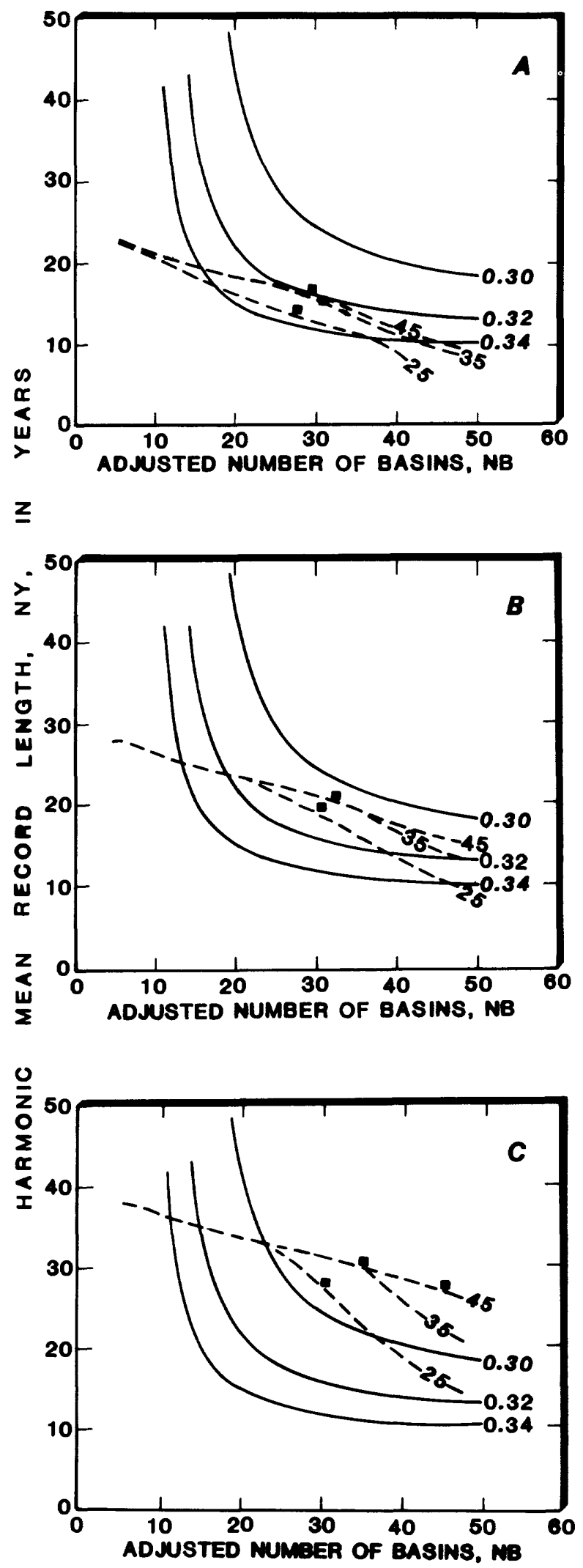

Figure 3.--NB-NY frontier overlaid on lines of standard error of estimate for the two year peak food analysis. 


\section{GAGING-NETWORK DESIGN - Continued}

To achieve the 20-yr planning horizon point of minimum error for 25 stations, the 16 designated stations in table 2 would need to be operated for 20 years. Nine additional stations, of which up to 5 could be new stations, would also need to be maintained. This gaging plan clearly will "move" the network along a path of relatively rapid decrease in standard error of estimate: For future modeling work and prediction of significant statistics of Puerto Rico's water resources, it is essential that long-term stations be maintained. Presently, there are only six operating stations that have 20 or more years of record.

In developing this plan, consideration was given only to estimating the mean-annual flow and the flood-frequency statistics previously described. Low-flow statistics, perhaps more important than mean and peak flows, cannot be estimated from these procedures. If the only purpose for collecting data at a particular site is to collect regional information about the mean and peak flows, stations not included in table 3 , could be discontinued if the regression model and standard error described are acceptable to the data user. However, many of those stations are special purpose at the request of other Federa1 and Commonwealth agencies and are designed to provide other flow statistics.

A word of caution must be added to avert a tendency to over simplify. Actual deviation from predicted discharges at individual stations will differ from the standard error noted for the regression equations. This difference may be quite large in either the positive or negative direction. Therefore, when the regression equation is used to define discharges at a site with little or no data, the manager must remember that he is working with statistical averages and not absolutes.

\section{CONCLUSIONS}

The evaluation of Puerto Rico's surface-water streamgaging network by the NARI technique suggests a more efficient network. It is clear from the analysis that some stations can be discontinued while decreasing the sampling error associated with estimation of mean-annual flow and flood frequency. The recommended network is listed in table 4. Sites listed as long-term is considered the foundation of the dicharge data collection program. A station for a special project that is presently unforeseen can be added to this list, but, should not replace a long-term station unless the overall system is reanalyzed. 01d project stations and network stations that were originally designed as short term stations were selected to be discontinued.

There are other hydrologic occurrences, such as low flows, that are equally as important in network planning as those analyzed in this report. This should be kept in mind when reviewing the network set forth here. Additional stations may be required to satisfy other needs, but are not considered in this study. 
Table 4.--Recommended network and cooperators.

\begin{tabular}{|c|c|c|c|}
\hline $\begin{array}{l}\text { STATION } \\
\text { NUMBER }\end{array}$ & STATION NAME & COOPERATOR & STATUS \\
\hline 50028000 & Río Tanamá nr Utuado & $\mathrm{EQB}$ & */LT \\
\hline 50029000 & Río Gde de Arecibo at Cambalache & EQB-DOA & */LT \\
\hline 50030460 & Río Orocovis nr Orocovis & DNR & $* / D$ \\
\hline 50031200 & Río Grande de Manatí nr Morovis & $\mathrm{EQB}$ & $\mathrm{D}$ \\
\hline 50034000 & Río Bauta nr Orocovis & $\mathrm{EQB}$ & $\mathrm{D}$ \\
\hline 50035000 & Río Gde de Manatí at Ciales & $\mathrm{EQB}$ & ST \\
\hline 50038100 & Río Gde de Manatí Hwy 2 nr Manatí & $\mathrm{EQB}$ & $\mathrm{LT}$ \\
\hline 50038320 & Río Cibuco below Corozal & $\mathrm{EQB}$ & ST \\
\hline 50039500 & Río Cibuco at Vega Baja & $\mathrm{EQB}$ & ST \\
\hline 50043000 & Río de la Plata at Proj. La Plata & $\mathrm{EQB}$ & ST \\
\hline 50046000 & Río de la Plata at Toa A1ta & $\mathrm{EQB}$ & $\mathrm{LT}$ \\
\hline 50049000 & Río Piedras at Río Piedras & $\mathrm{EQB}$ & $\mathrm{D}$ \\
\hline 50050900 & Río Gde de Loíza at Quebrada Arenas & COE-PRASA & */ST \\
\hline 50051310 & Río Cayaguas at Cerro Gordo & COE-PRASA & */ST \\
\hline 50055000 & Río Gde de Loíza at Caguas & EQB-PRASA & */LT \\
\hline 50056400 & Río Valenciano nr Juncos & EQB-PRASA & LT \\
\hline 50057000 & Río Gurabo at Gurabo & EQB-PRASA & $\mathrm{LT}$ \\
\hline 50061800 & Río Canóvanas nr Campo Rico & $\mathrm{EQB}$ & $\mathrm{ST}$ \\
\hline 50063800 & Río Espíritu Santo nr Río Grande & $\mathrm{EQB}$ & $\mathrm{D}$ \\
\hline 50064200 & Río Grande nr E1 Verde & $\mathrm{EQB}$ & $\mathrm{D}$ \\
\hline 50065700 & Río Mameyes at Hwy 191 at Mameyes & $\mathrm{EQB}$ & $\mathrm{D}$ \\
\hline 50067000 & Río Sabana nr Sabana & $\mathrm{COE}$ & */ST \\
\hline 50071000 & Río Fajardo nr Fajardo & $\mathrm{COE}$ & */LT \\
\hline 50075000 & Río Icacos nr Naguabo & $\operatorname{COE}$ & $\star / D$ \\
\hline 50076000 & Río Blanco nr Florida & PRASA & $\mathrm{N} / \mathrm{LT}$ \\
\hline 50082000 & Río Humacao at Hwy 3 at Humacao & PRASA & $\mathrm{N} / \mathrm{ST}$ \\
\hline 50082800 & Río Guayanés nr Colonia Laura & $\mathrm{EQB}$ & $\mathrm{D}$ \\
\hline 50090500 & Río Maunabo at Liza & $\mathrm{EQB}$ & $\mathrm{ST}$ \\
\hline 50092000 & Río Gde de Patillas nr Patillas & NASQAN & $\mathrm{LT}$ \\
\hline 50112500 & Río Inabón at Real Abajo & $\mathrm{EQB}$ & $\mathrm{LT}$ \\
\hline
\end{tabular}


Table 4.--Continued

\begin{tabular}{|c|c|c|c|}
\hline $\begin{array}{l}\text { STATION } \\
\text { NUMBER }\end{array}$ & STATION NAME & COOPERATOR & STATUS \\
\hline 50114000 & Río Cerrillos nr Ponce & $\mathrm{COE}$ & */ST \\
\hline 50115000 & Río Portugués nr Ponce & $\mathrm{COE}$ & */ST \\
\hline 50124200 & Río Guayanilla nr Guayanilla & $\mathrm{EQB}$ & $\mathrm{LT}$ \\
\hline 50126150 & Río Yauco nr Monserrate Div. Yauco & DNR & */ST \\
\hline 50128000 & Río Yauco nr Yauco & DNR & $* / \mathrm{ST}$ \\
\hline 50128950 & Lajas Irrigation & DOA & $* / \mathrm{ST}$ \\
\hline 50129300 & Lajas Drainage Canal nr Ensenada & DOA & */ST \\
\hline 50136000 & Río Rosario at Rosario & $\mathrm{EQB}$ & ST \\
\hline 50138000 & Río Guanajibo nr Hormigueros & EQB-PRASA & LT \\
\hline 50141000 & Río Yahuecas nr Adjuntas & EQB & */ST \\
\hline 50141100 & Yahuecas Reservoir nr Castañer & DOA & */LT \\
\hline 50141500 & Guayo Reservoir nr Castañer & DOA & */ST \\
\hline 50142500 & Prieto Reservoir nr Castañer & DOA & */ST \\
\hline 50144000 & Río Gde de Añasco nr Sebastiān & NASQAN & LT \\
\hline 50147800 & Río Culebrinas at HWY $404 \mathrm{nr}$ Moca & $\mathrm{EQB}$ & $\mathrm{LT}$ \\
\hline
\end{tabular}

EXPLANATION FOR TABLE 4

\section{COOPERATORS:}

$\mathrm{EQB}$, Environmental Quality Board;

DOA, Department of Agriculture;

DNR, Department of Natural Resources;

PRASA, Puerto Rico Aqueduct and Sewer Authority;

COE, U.S. Army Corps of Engineers;

NASQAN, National Stream Quality Accounting Network.

\section{STATUS:}

*, presently a project site;

$\mathrm{N}$, New project station;

LT, Long term-20 years or more;

ST, Short term-5 years or more;

D, Discontinuation recommended. 


\section{LIST OF REFERENCES}

Barr, A. J., Goodnight, J. H., Sal1, J. P., and Helwig, J. T., 1976, A user's guide to SAS 76: Raleigh, N.C., SAS Institute, Inc. 329 p.

López, M. A., Colón-Dieppa, Eloy, and Cobb, E. D., 1979, Floods in Puerto Rico, magnitude and frequency: U.S. Geological Survey Water Resources Investigations 78-141, 66 p.

Moss, M. E., Gilroy, E. J., Tasker, G. D., and Karlinger, M. R. 1982, Design of surface water data networks for regional information: U.S. Geological Survey Water Supply Paper 2178, 33 p.

Moss, M. E., and Karlinger, M. R., 1974, Surface water network design by regression analysis simulation: Water Resources Research v. 10, no. (3), p. 427-433.

Moss, M. E., Lettenmaier, D. P., and Wood, E. F., 1978, On the design of hydrologic data networks: EOS, Transactions, American Geophysical Union, v. 59, no. 8, p 772-775. 